\title{
ANALISIS KEMAMPUAN BERPIKIR KREATIF MATEMATIS CALON GURU MATEMATIKA
}

\author{
Ali Umar, Nurul Qomariyah Ahmad \\ STAIN Gajah Putih Takengon, Aceh Tengah, Aceh \\ Email: ali_umar86@ymail.com
}

\begin{abstract}
Abstrak. Tulisan ini membahas kemampuan berpikir mahasiswa dalam menyelesaikan soal matematika berkategori soal berpikir kreatif matematis. Penelitian ini dilakukan dengan pendekatan penilitian deskriptif. Subjek penelitian adalah mahasiswa prodi tadris matematika STAIN Gajah Putih Takengon yang berjumlah 13 orang TA 2018/2019. Instrumen penelitian yang digunakan adalah soal tes berpikir kreatif matematis. Analisis data menggunakan The torrance tests of creative thinking (TTCT) yang terdiri dari tiga komponen yaitu kefasihan (fluency), fleksibelitas(flexibility), dan kebaharuan (novelty). Hasil penelitian disimpulkkan bahwa 1). Kemampuan berpikir kreatif mahasiswa masih sangat rendah dengan skor ratarata2,61 (berada pada level kurang kreatif. 2) komponen berpikir kreatif yang paling rendah adalah fleksibelitas dan kebaharuan.
\end{abstract}

Kata Kunci: kemampuan berpikir, kreatif matematis.

\section{Pendahuluan}

Kemampuan berpikir kreatif masih menjadi topik yang masih menarik dalam dunia pendidikan. Partnership for $21^{\text {st }}$ Century Skill (P21) dalam hasil penelitiannya menyarankan salah satu kemampuan yang harus ditumbuhkan kembangkan dalam pendidikan pada abad 21 adalah berpikir kreatif (www.p21.org). Urgensi dikembangkan kemampuan berpikir kreatif dalam dunia pendidikan adalah untuk membekali peserta didik dalam menyiapkan diri menghadapi tantangan hidup. Dimana kebutuhan semakin meningkat sumber daya semakin berkurang dan permasalahan semakin bertambah komplet. Peserta didik harus mampu memanfaatkan sumber daya sekreatif mungkin untuk kehidupan mereka yang lebih baik di masa depan. Bidang atau profesi apaun yang dipilih oleh peserta didik dalam kehidupannya pasti membutuhkan kemampuan berpikir kreatif.

Sudah banyak usaha yang dilakukan oleh Pemerintah untuk mengembangkan kemampuan berpikir kreatif peserta didik. Pada K-13 mensyaratkan dalam proses proses belajar mengajar harus mendukung para peserta didik untuk meningkatkan kemampuan berpikir kreatif. Hal ini tergambar secara implisit dalam prinsip pembelajaran K-13 (Permendikbud No 103, 2014). Tahun 2018 pemerintah mempersentasekan soal bertipe HOTS sebesar $10 \%$ dalam soal UN, kebijakan diterapkan untuk melatih siswa menggunakan kemampuannya untuk berpikir kritis dan kratif. Disamping itu kebijakan ini diterapkan untuk mendorong para guru meningkatkan kualitas pembelajaran. Keikutsertaan Indonesia di PISA semenjak tahun 2000 juga bertujuan untuk mengevaluasi dan meningkatkan kualitas pendidikan dengan memonitor kemampuan literasi memabaca, kemampuan matematika dan kemampuan sains anak usia 15 tahun.

Hanya saja, usaha yang dilakukan belum berbanding lurus dengan hasil yang dicapai dalam meningkatkan kemampuan berpikir kreatif siswa. Hasil PISA terbaru 
tahun 2015 memang mengalami peningkat seperti pada bidang matematika meningkat dari 275 poin pada tahun 2012 menjadi 386 poin pada tahun 2015. Berikut grafik hasil PISA tahun 2015.

Gambar 1. Hasil PISA Tahun 2015

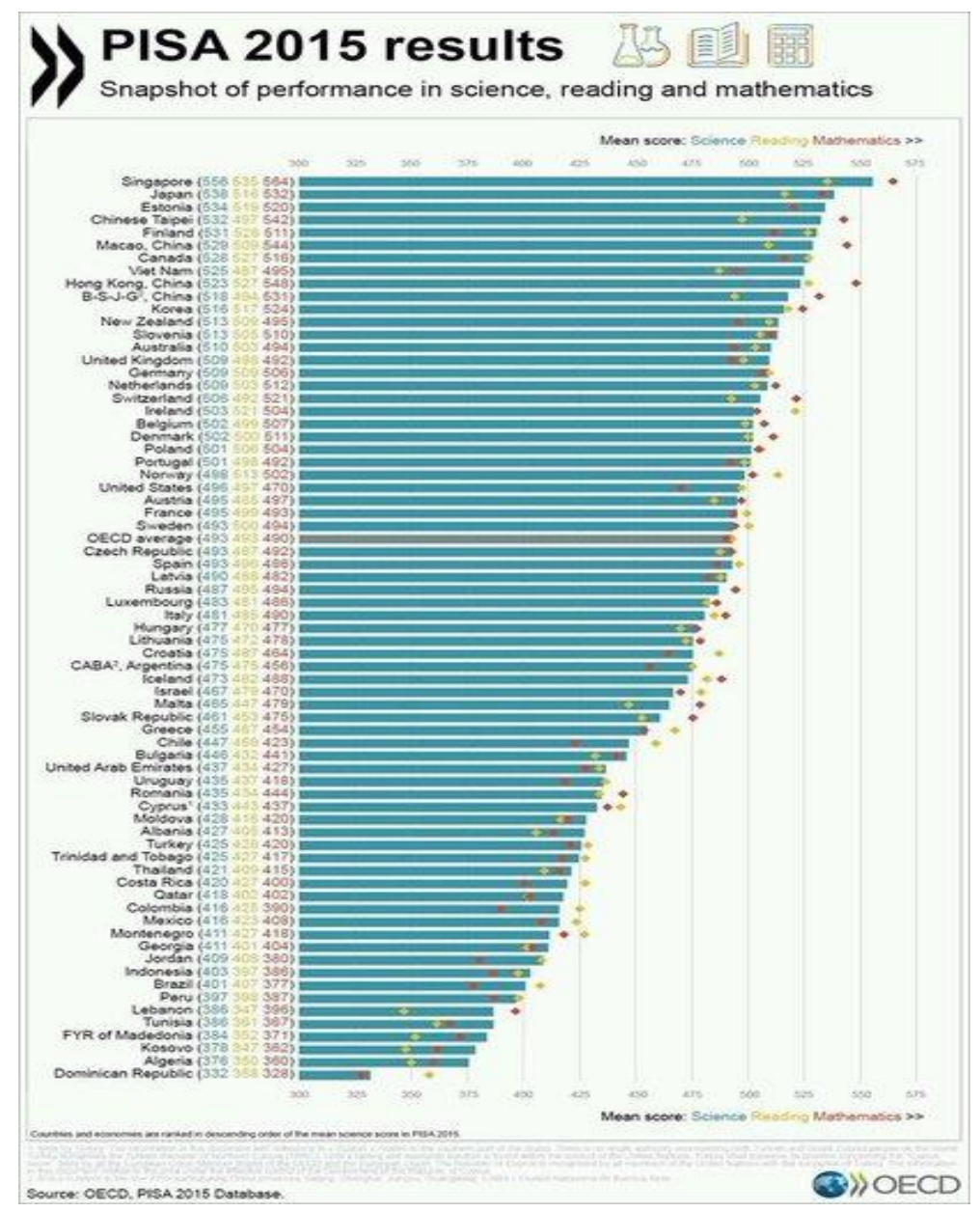

Sumber : OECD, PISA 2015 Database

Dari grafik tersebut dapat terlihat posisi indonesia berada pada posisi 9 dari bawah, kalah dari negara-negara tetangga bahkan sangat jauh tertinggal dari Singapuara yang menempati posisi pertama. Indikator lain yang menggambarkan lemahnya kemampuan matematika siswa Indonesia adalah hasil UN mata pelajaran matematika berada pada kategori kurang. Berikut rata-rata hasil UN tahun 2018 
Tabel 1. Rekapitulasi Hasil UN Mata Pelajaran Matematika Tiap Tingkatan Secara Nasional

\begin{tabular}{|l|c|c|c|}
\hline \multirow{2}{*}{ Statistik } & \multicolumn{3}{|c|}{ Jenjang Pendidikan } \\
\cline { 2 - 4 } & SMP & SMA & SMK \\
\hline Kategori & Kurang & Kurang & Kurang \\
\hline Rata-rata & 43,34 & 35 & 33,73 \\
\hline Terendah & 50 & 5 & 5 \\
\hline Tertinggi & 100 & 100 & 100 \\
\hline Standar Deviasi & 17,98 & 15,71 & 13,65 \\
\hline
\end{tabular}

Sumber: https://puspendik.kemdikbud.go.id/hasil-un/

Bahkan secara umum hasil UN untuk tiap tingkatan mengalami trend penurunan dari tahun pelajaran 2014/2015 s/d 2017/2018. Penyebab menurunnya hasil UN ini disinyalir karena meningkatnya nilai integritas pelaksanaan UNBK dan munculnya soal HOTS di UNBK (Ega Gradini, 2018). Meningkatnya nilai integritas pelaksanaan UNBK berarti pelaksanaan ujian berjalan dengan lancar dan menurunnya tingkat kecurangan sementara munculnya soal HOTS membuat tingkat kesulitan soal menjadi lebih tinggi. Fakta ini harus disikapi positif oleh para guru dengan cara meningkatkan kompetensi mereka. Kompetensi yang harus ditingkatkan oleh guru tersebut meliputi kompetensi pedagogik, kompetensi kepribadian, kompetensi sosial dan kompetensi profesional (UU Guru dan Dosen No 14, 2005). Pentingnya peningkatan kompetensi guru karena kualitas pendidikan sangat tergantung dengan guru. Zusmela dkk(2017) menyatakan tugas seorang guru mulai dari tranfer of knowledge sampai ke transfer of value serta memberi contoh yang baik kepada peserta didik. Sebab tidak bisa dipungkiri kualitas guru di Indonesia masih sangat butuh peningkatan yang signifikan. Salah satu bukti adalah ratarata hasil ujian kompetensi guru (UKG) secara nasional tahun 2018 baru mencapai 53,02 atau masih dibawah standar kompetensi minimal yakni 55,0 (http://itjen.kemendikbud.go.id).

Meningkatkan kompetensi guru harus sudah dilakukan dibangku pendidikan calon guru. Di dalam dunia perguruan tinggi tujuan mahasiswa belajar bukan sekedar mendapatkan nilai tinggi akan tetapi mendapatkan ilmu yang akan diterapkan ketika terjun kedalam masyarakat. Sebagaimana halnya para mahasiswa calon guru matematika di STAIN Gajah Putih. Mereka harus disiapkan sebagai tenaga ahli yang nantinya berkarir di dunia pendidikan matematika. Materi-materi yang mereka dapatkan harus sejalan dengan perkembangan dunia pendidikan. Misalnya, ketika kurikulum-kurikulum sebelum K-13 matematika di ajarkan di sekolah agar para siswa memahami konsep materi dan mampu menjawab soal dengan benar, akan tetapi pada perkembangan selanjutnya pendidikan matematika tidak lagi sekedar memahami konsep. Pendidikan matematika diajarkan agar kemampuan-kemampuan yang lebih spesifik meningkat, seperti kemampuan penalaran matematis, kemampuan pemecahan masalah, kemampuan koneksi matematis, kemampuan berpikir kritis dan kreatif matematis dimana kemampuan ini dikategorikan sebagai kemampuan tingkat tinggi atau Hight Order Thinking Skill (HOTS). Fakta-fakta ini harus menjadi pertimbangan dalam kegiatan pendidikan calon guru tersebut. 
Sehubungan dengan hal tersebut menganalisis kemampuan mereka merupakan bagian dari upaya meningkat kompetensi sebagai calon guru. Hasil analsis tersebut akan menjadi bahan patokan dalam kegiatan pengajaran. Memperhatikan fakta-fakta tersebut, maka artikel ini membahas tentang kemampuan berpikir kreatif para calon guru dalam menjawab soal-soal berorientasi berpikir kreatif matematis.

\section{Kajian Teori}

Berpikir kreatif terdiri dari dua kata yaitu "berpikir" dan "kreatif. Ruggiero dalam Siswono(2018) mengartikan berpkir sebagai suatu aktivitas mental untuk membantu memformulasikan datau memecahkan suatu masalah, membuat suatu keputusan, atau memenuhi syarat keingintahuan (fullfil a desire to understand). Sementara Santrock (2010) menyatakan bahwa berfikir adalah memanipulasi atau mengelola dan mentransformasi informasi dalam memori. Ini sering dilakukan untuk membentuk konsep, bernalar dan berfikir secara kritis, membuat keputusan, berfikir kreatif dan memecahkan masalah. Berdasarkan prosesnya berfikir dapat dikelompokkan dalam berfikir dasar dan berfikir kompleks. Proses berfikir kompleks yang disebut berfikir tingkat tinggi meliputi pemecahan masalah, pengambilan keputusan, berfikir kritis dan berfikir kreatif.

Sedangkan kreatif adalah memiliki daya cipta atau memiliki kemampuan untuk menciptakan ( https://kbbi.web.id/kreatif ). kreatif atau kreativitas dapat diartikan kedalam berbagai pendekatan. Dalam bukunya siswono (2018) mengungkap pendekatan berbagai ahli seperti ahli yang menggunakan pendekatan proses menyatakan bahwa kreativitas adalah sebuah kegiatan atau cara yang untuk menciptakan sesuatu yang baru yang tidak ada sebelumnya melalui pengalaman-pengalama yang sudah ada. Ahli yang menggunakan pendekatan individu mengartikan kreativitas adalah orang yang mampumenyusun rencana, menentukan strategi dan memecahkan masalah serta terampil dalam mengambil keputusan, mampu melakukan dengan cara-cara sendiri, tertarik dengan sesuatu yang menuntut kreativitas. Definisi yang menekankan kepada faktor pendorong mengartikan kreatifitas adalah kemampuan untuk mendobrak pemikiran yang biasa pada umumnya dan tidak suka dengan budaya-budaya yang terlampu ketat dan mengikat. Definisi yang. Definis yang menekankan pada proses mengartikan kreativitas sebagai sebuah proses yang membuat produk-produk baru dimana produk tersebut sesuai dengan tujuan yang dibuat dan merupakan produk baru yang berbeda dari sebelumnya.

Sementara berpikir kreatif menurut Coleman dan Hammen seperti yang dikutip oleh Sukmadinata bahwa "Berfikir kreatif adalah suatu kegiatan mental untuk meningkatkan kemurnian (originality) dan ketajaman pemahaman (insight) dalam mengembangkan sesuatu (generating)". Kemampuan berfikir kreatif berkenaan dengan kemampuan menghasilkan atau mengembangkan sesuatu yang baru, yaitu sesuatu yang tidak biasa yang berbeda dari ide-ide yang dihasikan kebanyakan orang (Sukmadinata, 2012). berpikir kreatif dapat juga diartikan sebagai sebuah kegiatan berpikir yang dilakukan oleh seseorang, dimana goal dari berpikir tersebut adalah munculnya sesuatu yang baru.hal ini senada dengan yang dinyatakan oleh He (2017) bahwa berpikir kretaif mempunyai tujuan yang jelas dan diawali dengan perencanaan dan persiapan yang hatihati.

Terdapat empat tahap dalam berfikir kreatif, yaitu; (1) Exploring, mengidentifikasi hal-hal apa saja yang ingin dilakukan dalam kondisi yang ada pada saat ini; (2) Inenting, melihat atau mereview berbagai alat, teknik, dan metode yang telah 
tradisional; (3) Choosing, mengidentifikassi dan memilih ide-ide yang paling mungkin untuk dilaksanakan; (4) Implementing, bagaimana membuat suatu ide dapat diimplementassia (Estianah, 2013).

Williams menyatakan Seorang dikatakan mampu berpikir kreatif jika orang tersebut mampu berpikir dalam tiga kategori yaitu kefasihan, fleksibelitas, orisinalitas dan elaborasi (Siswono, 2018). Kefasihan adalah kemampuan untuk menghasilkan pemikiran atau pertanyaan dalam jumlah banyak, keluasan adalah kemampuan untuk berpindah dari satu pemikiran ke pemikiran lainnya, orisinalitas adalah kemampuan untuk menghasilkan pemikiran yang different berbeda dari yang sudah ada sedangkan elaborasi adalah kemampuan untuk melihat secara rinci berbagai situasi dan gagasan. Keempat gagasan ini dijadikan oleh Silver sebagai indikator untuk menilai kemampuan berpikir kreatif seseorang. Alat tes yang digunakannya disebut dengan The Torrance Tests of Creative Thinking (TTCT) (Siswono, 2018).

Sementara Kemampuan berpikir kreatif matematis seperti yang dikemukan oleh Muandar bahwa kemampuan tersebut meliputi empat kriteria yaitu kelancaran peserta didik dalam menyelesaikan masalah matematika secara tepat, kelenturan dalam mengemukan gagasan terhadap permasalahan akan tetapi tidak lari dari masalah yang ada, keaslian jawaban yang berasal dari ide mereka sendiri serat kemampuan mengembangkan gagasan sendiri ataupun orang lain (Amidi, 2016). Marliani juga menjelaskan Kemampuan berfikir kreatif matematis dapat diartikan sebagai kemampuan menyelesaikan masalah dengan mudah, sederhana, dan fleksibel yang ada hubungannya dengan matematika, selain itu berpikir kreatif matematis sangat diperlukan untuk melatih kemampuan berpikir logis, analitis, sistematis, kritis dan kreatif, serta memiliki kemampuan bekerjasama (Marliani, 2015).

Berdasarkan pengertian-pegertian tersebut terlihat bahwa kemampuan kreatif matematis tidak bisa selalu dinilai dengan produk-produk nyata yang dihasilkan sebagaimana hasil produk kreatif pada umumnya. Akan tetapi dapat dilihat dari kemampuan seseorang dalam menyelesaikan masalah yang diberikan secara tepat, sederhana, menggunakan berbagai macam cara yang dapat dia lakukan.

Kemampuan berpikir kreatif matematis peserta didik sama halnya dengan kemampuan-kemampuan yang lain. Maksidnya kemampuan tersebut bisa ditingkatkan melalui latihan, memahami faktor-faktor yang dapat meningkatkannya dan menggunakan cara yang tepat untuk meningkatkannya. Kemampuan berpikir matematis peserta dapat dikategorikan menjadi 4 tingkatan yaitu

Tabel 2. Tingkatan Berpikir Kreatif matematis Siswa

\begin{tabular}{|l|l|}
\hline Tingkat & Karakteristik \\
\hline $\begin{array}{l}\text { Tingkat 4 } \\
\text { (Sangat Kreatif) }\end{array}$ & $\begin{array}{l}\text { Peserta didik mampu menunjukan kefasihan, fleksibelitas dan } \\
\text { kebaharuan dalam memecahkan masalah dan mengajukan } \\
\text { masalah }\end{array}$ \\
\hline $\begin{array}{l}\text { Tingkat 3 } \\
\text { (kreatif) }\end{array}$ & $\begin{array}{l}\text { Peserta didik mampu menunjukan kefasihan dan kebaharuan atau } \\
\text { kefasihan dan fleksibelitas dalam memecahkan masalah maupun } \\
\text { mengajukan masalah }\end{array}$ \\
\hline $\begin{array}{l}\text { Tingkat 2 } \\
\text { (Cukup Kreatif) }\end{array}$ & $\begin{array}{l}\text { Peserta didik mampu menunjukan atau fleksibelitas dalam } \\
\text { memecahkan masalah atau mengajukan masalah }\end{array}$ \\
\hline
\end{tabular}




\begin{tabular}{|l|l|}
\hline $\begin{array}{l}\text { Tingkat 1 } \\
\text { (Kurang Kreatif) }\end{array}$ & $\begin{array}{l}\text { Peserta didik mampu menunjukan kefasihan dan memecahkan } \\
\text { masalah atau mengajukan masalah }\end{array}$ \\
\hline $\begin{array}{l}\text { Tingkat } 0 \\
\text { (tidak Kreatif) }\end{array}$ & $\begin{array}{l}\text { Peserta didik tidak mampu menunjukan ketiga aspek indikator } \\
\text { tersebut }\end{array}$ \\
\hline
\end{tabular}

Siswanto (2018)

\section{Metode Penelitian.}

Peneltian ini menggunakan metode pendekatan penelitian deskrptif. Subjek penelitian adalah seluruh mahasiswa Prodi tadris matematika semester 4 STAIN Gajah Putih Taknegon yang berjumlah 13 orang. Instrumen penelitian yang digunakan adalah Soal tes kemampuan berpikir Kreatif. Hasil tes dianalisis dengan menggunakan The torrance tests of creative thinking (TTCT) yang terdiri dari tiga komponen yaitu kefasihan (fluency), fleksibelitas(flexibility), dan kebaharuan (novelty). Hasil test kemudian dikonfrontasi dengan hasil wawancara untuk mendapatkan informasi lebih terperinci mengenai jawaban subjek. Berikut adalah pedoman penskoran soal test kemampuan berpikir kreatif matematis.

Tabel 1. Pedoman penskoran jawaban tes kemampuan berpikir kreatif

\begin{tabular}{|l|l|}
\hline \multicolumn{1}{|c|}{ Indikator } & \multicolumn{1}{c|}{ Penilaian } \\
\hline Penyelesaian & $\begin{array}{l}\text { Jawaban tugas benar, skor 1 } \\
\text { Jawaban salah, skor 0 (tidak dilanjutkan penilaian) }\end{array}$ \\
\hline $\begin{array}{l}\text { Kefasihan } \\
\text { jawaban atau } \\
\text { cara beragam) }\end{array}$ & $\begin{array}{l}\text { Jawaban benar lebih dari 1 dan berbeda dengan jawaban pertama, } \\
\text { skor 2 } \\
\text { Jawaban benar, dengan satu jawaban berbeda, tetapi cara } \\
\text { penyelesaian sama, maka skor 1 }\end{array}$ \\
\hline Fleksibelitas & $\begin{array}{l}\text { Cara penyelesaian lebih dari 1 cara dan berbeda secara konseptual, } \\
\text { maka skor 2 } \\
\text { Cara penyelesaian lebih dari 1 cara dan tidak berbeda secara } \\
\text { konseptual (beragam) maka skor 1 } \\
\text { Cara penyelesaian sama dengan yang dibuat pertama, maka skor 0 }\end{array}$ \\
\hline Kebaharuan & $\begin{array}{l}\text { Jawaban lebih dari satu jawaban dan berbeda, tidak menunjukan } \\
\text { berpola, skor 2 } \\
\text { Cara lebih dari 1 cara berbeda, tidak menunjukan berpola, skor 2 } \\
\text { Jawaban atau cara lebih dari 1 hanya beragam, maka skor 0 } \\
\text { Jawaban atau cara tidak lebih dari 1 dan hanya beragam maka skor 0 }\end{array}$ \\
\hline Skor maksimum & 7 \\
\hline
\end{tabular}

(Siswono, 2018) 


\section{Hasil dan Pembahasan}

Test berpikir kreatif diberikan kepada 13 subjek dengan waktu pengerjaan 45 menit. Soal tersebut terdiri dari satu masalah dengan pertanyaan-pertanyaan untuk mengukur kemampuan tiap indikator berpikir kreatif. Berikut adalah soal test yang diberikan:

Perhatikan ikan mas berikut (Siswono, 2018)

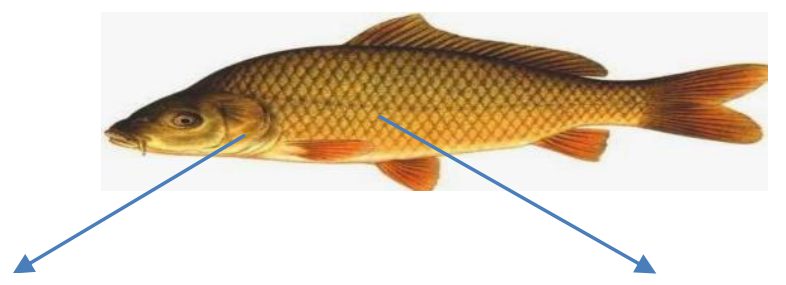

1. Dapatkah kamu memperkirakan berapa bobot ıkan tersebut! tuılskan aıasannya

2. Mungkinkah ada jawaban lain, bila ada sebutkan minimal dua jawaban (kefasihan)

3. Periksa jawaban nomor 2, tunjukan cara berbeda dalam menyelesaikannya (fleksibelitas)

4. Dapatkah kamu menentukan persamaan umum untuk menentukan tiap bagian ikan jika diketahui berat ikan tersebut? (kebaharuan)

Berikut ringkasan hasil tes jawaban subjek setelah dinilai dengan pendoman penskoran berpikir kreatif

Tabel 3. Rekapitulasi Hasil Tes

\begin{tabular}{|c|c|c|c|c|c|}
\hline \multirow{2}{*}{ Subjek } & \multicolumn{5}{|c|}{ Komponen berpikir kreatif } \\
\cline { 2 - 6 } & Penyelesaian & Kefasihan & Fleksibelitas & Kebaharuan & $\begin{array}{c}\text { Total } \\
\text { Skor }\end{array}$ \\
\hline 1 & 0 & 0 & 0 & 0 & 0 \\
\hline 2 & 1 & 2 & 1 & 0 & 4 \\
\hline 3 & 0 & 0 & 0 & 0 & 0 \\
\hline 4 & 1 & 2 & 1 & 0 & 4 \\
\hline 5 & 1 & 2 & 2 & 1 & 6 \\
\hline 6 & 1 & 2 & 1 & 0 & 4 \\
\hline 7 & 0 & 0 & 0 & 0 & 0 \\
\hline 8 & 1 & 2 & 1 & 0 & 4 \\
\hline 9 & 1 & 2 & 1 & 0 & 4 \\
\hline 10 & 0 & 0 & 0 & 0 & 0 \\
\hline 11 & 1 & 2 & 1 & 0 & 4 \\
\hline 12 & 1 & 2 & 1 & 0 & 4 \\
\hline 13 & 0 & 0 & 0 & 0 & 0 \\
\hline
\end{tabular}


Berdasarkan tabel, terlihat tidak satupun mahasiswa yang mendapatkan skor maksimum. Skor tertinggi adalah 6 dan skor terendah 0, dengan rata-rata 2,61. Rata-rata terendah berada pada aspek kebaharuan dan rata-rata tertinggi pada aspek penyelesaian soal biasa. Jika dikategorikan kedalam tingkatan kreatif maka rata-rata ini berada pada level kurang kreatif

Soal nomor 1 adalah soal penyelesaian biasa seperti pada umumnya. Untuk menjawab soal tersebut kemampuan yang dibutuhkan mahasiswa adalah kemampuan operasi hitung dan konsep perbandingan. Ada 3 orang mahasiswa yang tidak mampu menyelesaikanya sehingga skor ketiga mahasiswa tersebut 0 . Dalam jawaban ke-3 mahasiswa ini mengindikasikan mereka tidak menguasai konsep perbandingan. Tampak jelas dari jawaban bahwa mereka tidak bisa memulai untuk mengolah informasi yang diberikan. Berikut salah satu jawaban mahasiswa untuk soal nomor 1

Gambar 2. Bentuk jawaban yang Salah pada Soal No 1

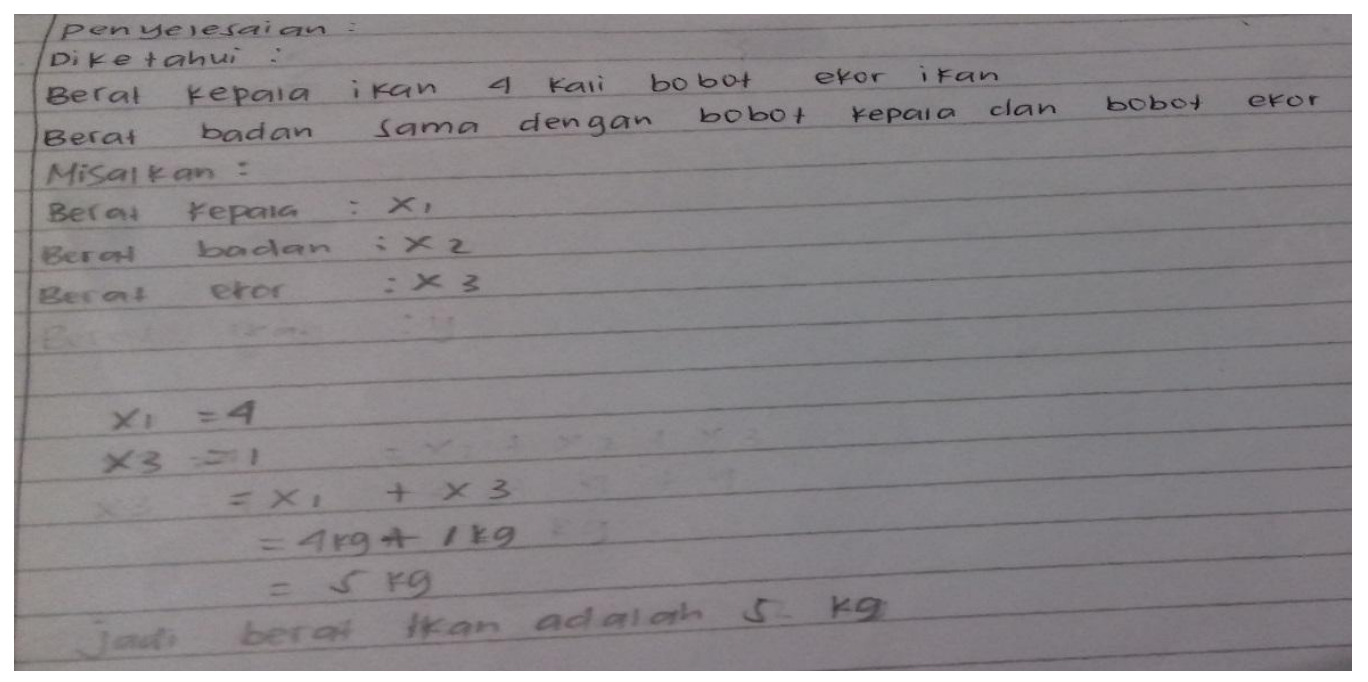

Pada gambar 2 tersebut terlihat mahasiswa memperkirakan berat ikan $5 \mathrm{Kg}$. dalam jawabannya mahasiswa tersebut memisalkan bagian-bagian ikan dengan berat kepala $X_{1}$, berat badan $\mathrm{X}_{2}$, Berat ekor $\mathrm{X}_{3}$, setelah itu memisalkan berat kepala $4 \mathrm{Kg}$ dan ekor $3 \mathrm{Kg}$. kedua bagian tersebut dijumlahkan untuk mendapatkan $5 \mathrm{Kg}$. Jelas mahasiswa tersebut tidak paham dengan yang dia kerjakan sebab menghilangkan bagian badan ikan.

Sementara ada dua mahasiswa yang menjawab akan tetapi tidak mensertakan alasan jawabannya sehingga skor kedua mahasiswa tersebut juga 0. Jawaban siswa pada nomor 1 pada umumnya mempunyai pola yang seragam. Jawaban tersebut diawali dengan menyelesaikan perbandingan kemudian mahasiswa memperkirakan berat 1 bagian untuk mendapatkan berat bagian yang lain setelah itu mejumlahkan seluruh bagian untuk mendapatkan berat total ikan.

Soal nomor 2 adalah soal untuk melihat kefasihan mahasiswa dalam menyelesaikan masalah. Pada soal tersebut mahasiswa dituntut untuk memperkirakan jawaban lain minimal dua kemungkinan jawaban. Sebanyak 8 mahasiswa yang menyelesaikan jawaban soal nomor 1 mampu dengan fasih menjawab soal nomor 2 . Ada dua tipe jawaban mahasiswa,yang pertama dengan menggunakan bahasa penalaran dan yang kedua dengan menggunakan bahasa aljabar. Kedua model jawaban tersebut dapat mewakili bentuk kefasihan mahasiswa dalam menyelesaikan soal yang diberikan. Berikut model diantara jawaban mahasiswa. 
Gambar 3. Jawaban mahasiswa dengan bahasa Aljabar

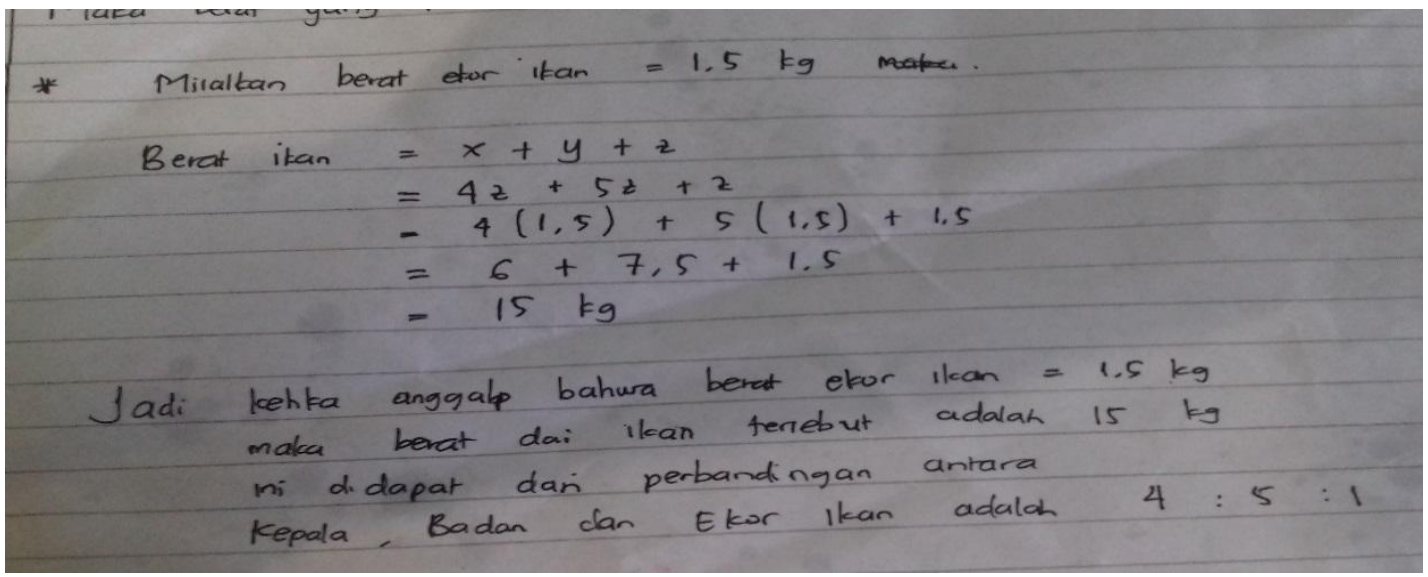

Gambar 4. Jawaban mahasiswa dengan bahasa penalaran

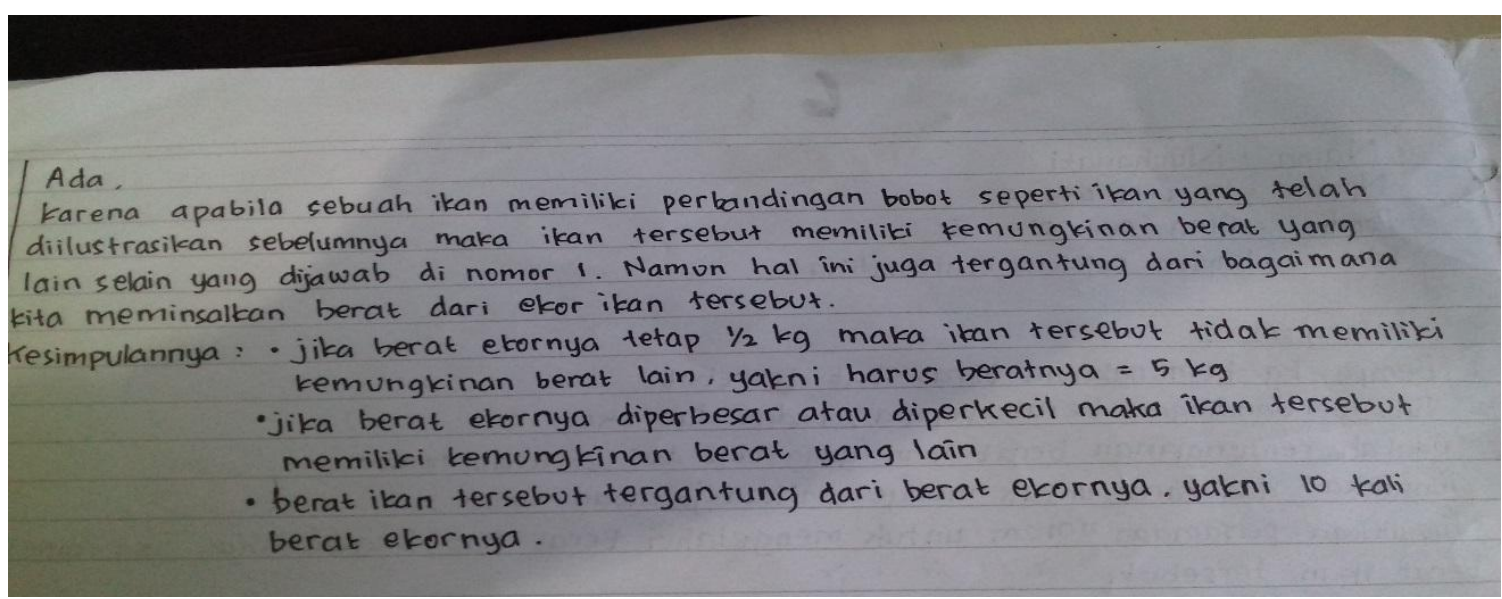

Sementara soal nomor 3, bertujuan untuk mengakses fleksibelitas mahasiswa dalam menyelesaikan masalah. Pada soal tersebut mahasiswa diminta untuk menyelesaikan jawaban soal nomor 2 dengan cara berbeda. Dari hasil analisis jawaban tidak ada satupun mahasiswa yang mampu menyelesaikan dengan cara yang berbeda. Jawaban berbeda yang diberikan mahasiswa hanya mempunyai satu cara yaitu dengan menggunakan pendekatan aljabar menggunakan simbol. Temuan ini menunjukan mahasiswa kurang fleksibel dalam menemukan solusi dari masih yang ditemukan.

Sedangkan soal nomor 4 sebagai soal terakhir berfungsi untuk melihat kebaharuan mahasiswa dalam menyelesaikan masalah. Mahasiswa dituntut untuk menemukan kebaharuan yang belum pernah ditemukan sebelumnya. Dalam soal ini mahasiswa diminta untuk membuat sebuah persamaan tentang berat bagian tiap ikan jika berat ikan total diketahui. Hasil analisis menunjukan tidak ada satupun mahasiswa mampu menyelesaikannya. Ada satu jawaban yang menarik. Berikut jawaban tersebut disalin sesuai dengan bentuk aslinya. 


$$
\begin{aligned}
& \text { karenax }=4 z \\
& y=4 z+z \\
& \text { maka } x+y+z=4 z+5 z+z
\end{aligned}
$$

Oleh karena itu diperoleh bahwa berat ikan tersebut adalah $10 z$

\section{Berat tiap ikan}

$$
\begin{aligned}
& \text { *kepala }: x \\
& x+y+z=10 z \\
& x+5 z+z=10 z \\
& x=10 z-6 z \\
& x=4 z
\end{aligned}
$$

*Badan :y

$$
\begin{aligned}
& x+y+z=10 z \\
& 4 z+y+z=10 z \\
& y=10 z-5 z \\
& x=5 z \\
& x+y+z=10 z \\
& 4 z+5 z+z=10 z \\
& 10 z=10 z \\
& z=1
\end{aligned}
$$

Berdasarkan jawaban tersebut terlihat mahasiswa menyelesaikan jawaban tanpa tujuan yang jelas. dalam jawaban tersebut tidak terlihat adanya rencana, mahasiswa tersebut hanya mengerjakan operasi aljabar yang bisa dikerjakan dalam persamaan yang dia buat. Jelas terlihat bahwa jawaban mahasiswa tersebut menujukan kurangnya kemampuan merinci informasi secara detail pada situasi yang diberikan atau dapat dikatakan kurangnya elaborasi.

\section{Kesimpulan dan Saran}

Setelah memperhatikan deskripsi analisis jawaban dapat disimpulkan bahwa mahasiswa belum mampu berpikir kreatif untuk menyelesaikan permasalahan yang diberikan, terutama pada aspek fleksibelitas dan kebaharuan. hal ini mengindikasikan bahwa kemampuan mahasiswa dalam menyelesaikan masalah berorientasi berpikir kreatif tidak berbeda dengan kemampuan siswa pada tingkat atas dan menengah. Melihat kondisi tersebut perlu adanya perubahan dilakukan perubahan yang mendasar pada aktifitas pembelajaran mahasiswa. Mahasiswa perlu dibiasakan menemukan solusi yang berbeda terhadap permasalahan yang diberikan. Model pembelajaran dikte model dituliskan masalah kemudian dosen menunjukan cara menjawabnya atau pembelajaran yang lebih menekankan pada hapalan harus dikurangi. Sebab model tersebut hanya 
melatih deduksi logis sementara intusi akan terbaikan. Akibatnya permasalahan yang berbeda dari yang sebelumnya diberikan akan sulit diselesaikan oleh mahasiswa. maka model pembelajaran terbaik sebagai gantinya adalah model yang menyeimbangkan logika dan intuisi. Model pembelajran sepertin ini sesuai dengan prinsip prinsip pembelajaran konstruktivisme yaitu menghadirkan masalah-masalah kuat relevansinya, menyusun pembelajaran di seputar konsep-konsep pokok, mencari tahu dan menghargai sudut pandang, memfasilitasi peserta didik untuk menemukan kekeliruan mereka sendiri bukan memberi tahu mereka secara langsung, menilai pembelajaran dengan penilai autentik(Schunk, 2012).

Dalam menciptakan kondisi pembelajaran yang ideal dibutuhkan kerjasama antara dosen dan mahasiswa. Kesamaan tujuan menjadi poin penting dalam proses kerjasama tersebut. Pola pikir mahasiswa harus berubah dari kuliah yang hanya ingin mendapatkan nilai tinggi menjadi pola pikir bahwa belajar diperguruan tinggi bertujuan untuk mendapatkan keahlian yang akan digunakan pada waktu terjun di dunia kerja.

Temuan ini menjadi catatan khusus bagi calon guru matematika, bahwa kemampuan siswa nantinya sangat berhubungan erat dengan kemampuan guru dalam kegiatan pembelajaran. Ketidamampuan siswa dalam memahami materi pelajaran tidak bisa disalahkan sepenuhnya kepada siswa akan tetapi berhubungna erat dengan kompetensi yang dimiliki oleh guru.

\section{Daftar Pustaka}

Amidi, M. S. (2016). Membangun kemampuan berpikir Kreatif matematis Dengan Model Pembelajaran Berbasis Masalah Berbantuan E-Learning. Seminar Nasional Matematika X Uneveristas Negeri Semarang (p. 588). Semarang: Universitas Negeri Semarang.

Ega Gradini, F. B. (2018). Menakar Kemampuan Berpikir Tingkat Tinggi Calon Guru Matematika Melalui Level Hots Marzano. Edu MA, 41-48.

Estianah, E. (2013). Meningkatkan Kemampuan Berfikir Kritis dan Kreatif Matematik Dengan Pendekatan Model Eliciting Activities (Meas) Pada Siswa SMA. Vol 2, No. 1. Infinity, 46.

He, K. (2017). A Theory of creative Thinking. Beijing: Springer.

http://itjen.kemendikbud.go.id, diakses tanggal 20 Dsember 2018

J.W.Santock. (2010). Psikologi Pendidikan (Edisi Kedua). Jakarta: Kencana.

Marliani, N. (2015). Peningkatan Kemampuan Berfikir Kreatif Matematis Siswa Melalui Model Pembelajaran Missouri Mathematics Project (MMP). .Jurnal Formatif, Vol 5 (1), 21.

Permendikbud No 103. (2014). Pembelajaran pada Pendidikan Dasar dan Menengah. Indonesia: Kemendikbud.

Schunk, Dale H. 2012. Learning Theories. Terjemahan oleh Eva Hamdiah dan Rahmat Fajar. Yogyakarta: Pustaka Pelajar

Siswono, T. Y. (2018). Pembelajaran Matematika Berbasis Pengajuan dan Pemecahan Masalah. Bandung: Remaja Rosdakarya. 
Sukmadinata. (2012). Kurikulum dan Pembelajaran Kompetensi. Bandung: Yayasan Kesuma Bangsa.

UU Guru dan Dosen No 14. (2005). Undang-undang Republik Indonesia NO TH 2005 tentang Guru dan Dosen. Jakarta: Republik INdonesia.

Wa Ode Lidya Arisanti, W. S. (2016). Analisis Penguasaan Konsep dan Keterampilan berfikir Kreatif Siswa SD melalui Project Based Learning . Edu Humaniora Vol 8(1),82-95.

www.p21.org. Diakses pada tanggal 31 Desember 2018.

Zusmelia, Irwan, Ramadoni, Rani Valicia Anggela.(2017). tantangan profesionalisme guru pada pembelajaran matematika melalui 4c's ditinjau dari perspektif sosiologi.Prosiding Seminar Nasional dan Workshop Matematika dan Pendidikan Matematika STKIP PGRI .Padang. MU-29. 